Many implants were lossed probably because of their size $(9 \mathrm{~cm})$.

Further trials would be necessary to obtain blocking of ostrus allowing artificial insemination on a predetermined day.

\title{
INDUCTION D'UNE GESTATION PENDANT LA LACTATION CHEZ LA TRUIE
}

\author{
F. MARTINAT, C. LEGAULT* et F. du MESNIL du BUISSON \\ Station de Physiologie de la Reproduction, \\ Centre de Recherches de Tours, I. N.R. A., \\ Nouzilly 37380 Monnaie \\ * Station de Génétique quantitative et appliquée, \\ Centre national de Recherches zootechniques, I. N. R. A., \\ 78350 Jouy en Josas
}

\section{RÉSUMÉ}

Les truies de deux troupeaux, Large White pour l'un, Piétrain pour l'autre, ont subi une

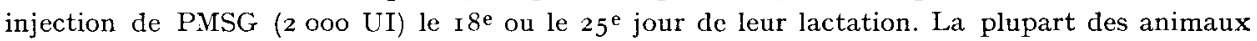
ont été traités au cours de deux lactations successives. La parités des truies étaient variables; le sevrage des porcelets a eu lieu $2 \mathrm{I}$ ou $3 \mathrm{I}$ jours après le traitement.

Sur I I I femelles traitées, 8 I ont manifesté un cestrus pendant la lactation soit, $72 \mathrm{p}$. Ioo dont 62 p. $100 \mathrm{le}_{4}$ et le $\mathrm{J}_{5}$ ( $\mathrm{J}_{0}$ étant le jour de l'injection). Dans le troupeau Piétrain, le taux d'cestrus induit diminue significativement lors du deuxième traitement.

37 p. roo des truies traitées ont mis bas à la suite d'une ovulation induite au cours de la lactation. Le nombre moyen de porcelets de ces portées est de 9,4 contre 10,4 pour les portées des truies fécondées après le sevrage (différence non significative). On constate une chute importante quoique non significative de la prolificité dans le troupeau Large White entre le premier et le second traitement.

Grâce à la relative constance de l'intervalle entre le traitement de l'apparition de l'œstrus, cette méthode est susceptible de faciliter l'utilisation de l'insémination artificielle.

\section{SUMMARY}

\section{INDUCTION OF PREGNANCY DURING LACTATING IN THE SOW}

Sows from two herds, the one Large White and the other Piétrain, received injection of PMSG ( 2 ooo IU) on day 18 or 25 of lactation. Most of the animals were treated during two successive lactations. The parities of the sows varied. Weaning of piglets occured 21 or $3 x$ days after treatment. 
$8 \mathrm{I}$ sows out of III treated (72 p. roo) exhibited cestrus during lactation, and among these, $62 \mathrm{p}$. Ioo on $\mathrm{D}_{4}$ and $\mathrm{D}_{5}\left(\mathrm{D}_{0}\right.$ being the day of injection). In the Piétrain herd, the induced œestrus rate decreased significantly after the second treatment.

37 p. Ioo of the treated sows farrowed after ovulation induced during lactation. The mean litter size was 9.4 versus 10.4 for litters of sows fertilized after weaning (non significant difference). A great fall, but non significant, in the prolificacy of the Large White herd was observed between the first and the second treatment.

Owing to the relative constancy of the interval between the treatment and the onset of ostrus, this mathod is liable to facilitate the utilization of artificial insemination.

\title{
SYNCHRONISATION DE L'GSTRUS POST-SEVRAGE DE LA TRUIE PAR INJEGTION DE PMSG
}

\author{
F. MARTINAT, F. du MESNIL du BUISSON et F. BARITEAU \\ Station de Physiologie de la Reproduction, \\ Centre de Recherches de Tours, I. N.R. A., \\ Nouzilly 37380 Monnaie
}

\section{RÉSUMÉ}

I 20 truies Large White ou Large White $\times$ Landrace ont reçu une injection intramusculaire de PMSG le jour du sevrage de leurs porcelets (lactation de 5 à 7 semaines).

La dose utilisée est de 2 ooo UI pour 99 truies et de I 200 UI pour 2 I truies. 90,8 p. Ioo des truies traitées viennent en œstrus entre le $J_{3}$ et le $J_{5}$. Ceci constitue un bon groupage de l'œstrus puisque dans les deux élevages où l'expérience a eu lieu, chez les témoins, le taux de venue en œstrus entre le $\mathrm{J}_{3}$ et $\mathrm{J}_{5}$ était respectivement de $4^{\mathrm{o}, 8}$ et $70,0 \mathrm{p}$. Ioo.

59,2 p. Ioo ont mis bas à la suite d'une double insémination faite à ce moment. On n'a pas mis en évidence de différences entre les deux doses de PMSG employées. La prolificité n'est pas modifiée d'une façon significative par le traitement.

Cette technique facilite donc l'insémination en groupe mais l'irrégularité des retours en œstrus de certaines truies peut constituer un handicap.

\section{SUMMARY \\ POST-WEANING SYNCHRONIZATION \\ OF OESTRUS IN THE SOW BY PMSG INJECTION}

I20 Large White or Large White $\times$ Landrace sows received an intramuscular injection of PMSG on the day when the piglets were weaned (lactation : 5-7 weeks).

The dosis used was 2000 IU for 99 sows and I 200 IU for 2 I sows. Onset of œstrus occured in $90.8 \mathrm{p}$. roo of the treated sows between $\mathrm{D}_{3}$ and $\mathrm{D}_{5}$. The blocking of cestrus was good since in 